\title{
Wintry habitat selection of the Zapallaren tree iguana (Liolaemus zapallarensis, Müller \& Hellmich, 1933) and its abundance in Changa beach, Coquimbo, northern Chile
}

\section{Selección de hábitat invernal del lagarto de Zapallar (Liolaemus zapallarensis, Müller \& Hellmich, 1933) y su abundancia en playa Changa, Coquimbo, norte de Chile}

\section{César Chávez-Villavicencio1,2,** \& Marcelo M. Rivadeneira ${ }^{3,4,5}$}

1Programa de Doctorado en Biología y Ecología Aplicada, Consorcio Universidad Católica del Norte y Universidad de La Serena, Calle Larrondo 1281, Región de Coquimbo, Chile. ${ }^{2}$ Centro Neotropical de Entrenamiento en Humedales, Calle Carmen Quiroga 421, La Serena, Coquimbo, Chile.

${ }^{3}$ Centro de Estudios Avanzados en Zonas Áridas (CEAZA), Av. Bernardo Ossandón 877, Coquimbo, Chile. Email: marcelo.rivadeneira@ceaza.cl

${ }^{4}$ Departamento de Biología Marina, Facultad de Ciencias del Mar, Universidad Católica del Norte, Larrondo 1281, Coquimbo, Chile.

${ }^{5}$ Departamento de Biología, Universidad de La Serena, La Serena, Chile.

*E-mail:cchavez@ucn.cl

\section{ABSTRACT}

Urban development modifies the habitat of reptiles where we expect, the individuals to select available sites with the quality necessary for their permanence. The aim of this study was to determine the variables that favored the habitat selection and abundance of The Zapallaren Tree Iguana Liolaemus zapallarensis, an endemic species of Chile, during a winter season in Changa beach, Coquimbo, in northern Chile. Between June and September 2017, we made 30 random visits to 18 plots of $900 \mathrm{~m}^{2}$ each. We estimated a resource selection probability function for presence-absence and abundance data using local habitat (e.g. slope, distance from the protection wall to the sea at low tide, interior height of the wall, mean height of the vegetation, rocky surface, and vegetal surface) and climatic variables (temperature, atmospheric pressure, direction and wind speed, solar radiation, and mean cloudiness) as predictors. Vegetation cover was the most important habitat variable explaining the presence of $L$. zapallarensis. In addition, increase in cloudiness and wind speed decreased the probability of selection. Manly's selectivity measure varied according to the established home ranges and the availability ratios within them. Finally, increase in cloudiness and wind speed decreased the abundance. Overall, our results show that the characteristics related to habitat and local climate influences the resource selection that favors the survival of reptiles. This work shows that beach sectors in urban contexts under anthropic pressure have important available resources that favor the presence and abundance of reptiles.

Keywords: behavioral ecology; ecological niche; lizards; resource selection.

\section{RESUMEN}

El desarrollo urbano modifica el hábitat de los reptiles donde se espera que los individuos seleccionen los sitios disponibles con la calidad necesaria para su permanencia. El objetivo de este estudio es determinar las variables que favorecen la selección de hábitat y abundancia de Liolaemus zapallarensis, especie endémica de Chile, durante una temporada invernal en Playa Changa, Coquimbo (norte de Chile). Entre junio y septiembre de 2017, se realizaron 30 visitas al azar a 18 parcelas de $900 \mathrm{~m}^{2}$ cada una. Se estimó una función de probabilidad de selección de recursos para datos de presencia-ausencia y abundancia utilizando variables de hábitat y climáticas como predictores. La cobertura de vegetación fue la variable de hábitat más importante que explicó la presencia de 
L. zapallarensis. Además, el aumento de la nubosidad y la velocidad del viento disminuyeron la probabilidad de selección. La medida de selectividad de Manly varió según los rangos de hogar establecidos y las proporciones de disponibilidad dentro de ellos. Finalmente, el aumento de la nubosidad y la velocidad del viento disminuyeron la abundancia. En general, los resultados muestran que la selección de recursos, que favorece la supervivencia de los reptiles, está fuertemente influenciada por características relacionadas con el hábitat y el clima local. Este trabajo muestra que los sectores de playa en contextos urbanos bajo presión antrópica tienen importantes recursos disponibles que favorecen la presencia y abundancia de reptiles.

Palabras clave: ecología del comportamiento; lagartijas; nicho ecológico; selección de recursos.

\section{INTRODUCTION}

Determining the most frequently selected habitat resources provides fundamental information about the nature of animals, the way they meet their need for survival and the quantitative information of a population's long-term requirements, which are useful for defining the hypothetical carrying capacity and project the impacts of habitat change (Manly et al. 2002). Urban development produces habitat fragmentation and the appearance of new habitats, which requires the native fauna to adapt to the challenges imposed by the transformation, reduce their population, move to suitable places, or disappear (Davis 1976, Dicken \& Doncaster 1987, Koenig et al. 2001; Fernández-Juricic 2004, Sierra 2012). Among the taxonomic groups that respond to these challenges are reptiles that often exhibit different behaviors and aspects of their natural history compared to their counterparts in more pristine environments (Gill \& Bonnett 1973).

There is a long tradition of studies of habitat use in lizards (Losos et al. 1993). Since different habitats have different abiotic and biotic conditions, the habitat choice can have important consequences at individual, population and community levels (Smith \& Ballinger 2001, Goodman et al. 2008). Within their habitat, individuals are rarely located at random, and they usually choose areas with characteristics that favor their development (Schlesinger \& Shine 1994, Kerr et al. 2003). However, the impact of urbanization on patterns of habitat selectivity in lizards has been scantly explored (Taylor et al. 2016).

The Zapallaren Tree Iguana, Liolaemus zapallarensis, an endemic species of Chile that is regularly found within its distribution range (Lobos et al. 2016), is distributed from Sarco Bay in the Atacama Region to Quintay in the Valparaíso Region, between 0 and 1200 m.a.s.I (Mella 2017). This species is of medium to large size with an mean snout-vent length of $104 \mathrm{~mm}$, of robust appearance, and it inhabits coastal scrub with rocks under bushes (Mella 2017). The species suffered drastic population losses during the 80's and early 90's due to poaching, and it has still not fully recovered. Despite multiple studies have shown habitat partitioning in Liolaemus species (Fuentes \& Jaksić 1980, Medel et al. 1988, Schulte et al. 2004, Tulli et al. 2009), at present no study has evaluated patterns of habitat selection in L. zapallarensis. This work aims to determine habitat and climatic variables, which favored the selection and abundance of $L$. zapallarensis during a winter season on a beach in northern Chile, highly modified by the need for tourism development.

\section{MATERIAL AND METHODS}

\section{STUDY SITE}

Changa Beach (Fig. 1) corresponds to a coastal strip of 1700 $\mathrm{m}$ in length located at the south of the Bay of Coquimbo, northern Chile, surrounded by the city. This strip presents minimum and maximum distances of $60 \mathrm{~m}$ and $190 \mathrm{~m}$, respectively, between the tide line and the wall that separates the beach from the pedestrian and vehicular infrastructure (Fig. 1). A Tsunami affected this area in September 2015 that produced changes in the landscape. Between the tide line and the highway there is a sandy beach with some patches of mainly herbaceous vegetation (Salicornia fruticosa and Carpobrotus chilensis), large rocks that protect the highway with some bushes and herbaceous vegetation, a separating wall in some sections and a pedestrian road between the wall and the highway that presents high frequency of vehicular traffic. The study area is subject to occasional swells, tidal movements, walking of feral dogs, cleaning activities, and removal of soil with tractors. $1200 \mathrm{~m}$ east of the beginning of the beach is the mouth of the El Culebron wetland. The presence of people dedicated to the extraction of drifted seaweed characterizes the first $700 \mathrm{~m}$ of the beach. The entire study area is open to pedestrian visitors who walk on the beach in less quantity in winter than in the summer. 
The mean temperature was $12.7^{\circ} \mathrm{C}$ with a minimum mean of $12.3{ }^{\circ} \mathrm{C}$ and a maximum mean of $13.2{ }^{\circ} \mathrm{C}$, while the accumulated rainfall during the winter season was $64.9 \mathrm{~mm}$ (http://www.ceazamet.cl).

\section{DATA COLLECTION}

Sampling was conducted during June and September of 2017 between 12.00 and 17.00 hours, without manipulating individuals and trying to cause as little damage as possible to the habitat. 18 random plots of $900 \mathrm{~m}^{2}$ were located, considering that similar species such as L. kuhlmanni and L. nitidus present home ranges between 75 and $776 \mathrm{~m}^{2}$ respectively (Simonetti \& Ortiz 1980, Fox \& Shipman 2003). We visited each plot 30 times in a random sequence. We recorded the time, presence or absence of the species while the climate data of temperature $\left({ }^{\circ} \mathrm{C}\right)$, atmospheric pressure $(\mathrm{hPa})$, direction and wind speed $(\mathrm{m} / \mathrm{s})$, solar radiation $\left(\mathrm{W} / \mathrm{m}^{2}\right)$ and mean cloudiness we obtained from local meteorological stations (http://www.ceazamet.cl) for the time of visit of each plot. In addition, in each plot, we measured the distance (m) from the protection wall to the sea at low tide, the interior height of the wall $(m)$, mean height of the vegetation $(m)$ measuring at 5 random points in the plot, rocky surface (\%) and vegetal surface (\%) using a GPS and ArcGis 10.5 software. At each visit, we counted the number of individuals observed in both inside and outside the plots in order to estimate the abundance of the species. We used the spatial position of individuals, determined using a GPS, to build home ranges with the fixed Kernel method (Worton 1989) in the sectors inhabited by the species separated by the stairs and ramps that serve as pedestrian access to the beach. We modified these home ranges by eliminating the parts where the species was not present. Subsequently, we established resource units, their availability within the home range and the use of each unit by the number of points registered.

\section{DATA ANALYSIS}

Resource selection of the species was analyzed with two approaches. (1) Resource selection probability function (RSPF) using a logistic regression based on presence/absence (1/0) data (Manly et al. 2002), with the site variables taken in the 18 plots and the climatic variables taken only in the plots where the species was present. (2) The most important resource selected by the species was analyzed with Manly's

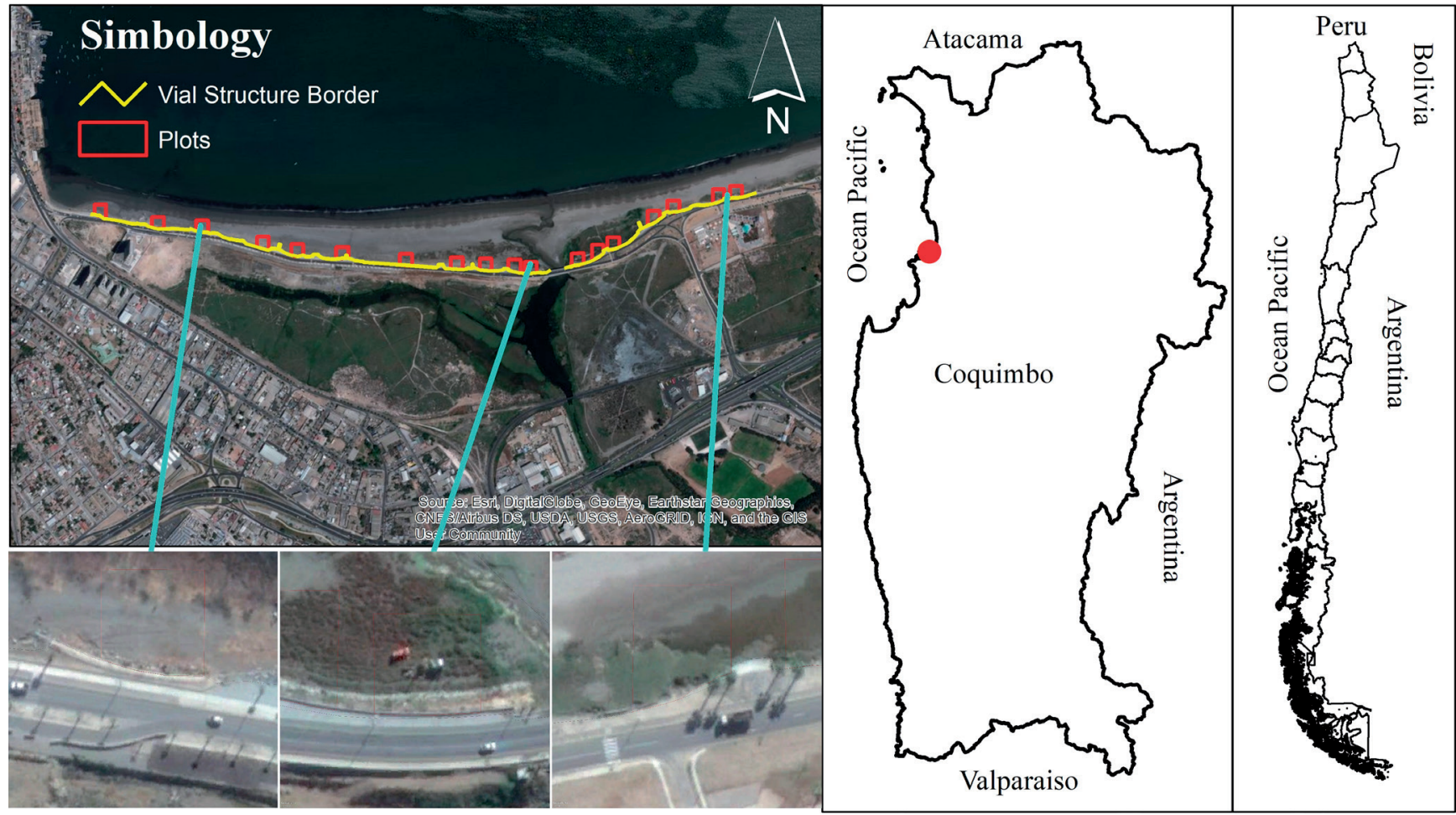

Figure 1. Study site location showing three sections. $1^{\text {st }}$ Down left: sand and vial structure. $2^{\text {nd }}$ Down middle: vegetation, wall rock and vial structure. $3^{\text {rd }}$ Down right: sand, vegetation and vial structure. / Ubicación del sitio de estudio mostrando las tres secciones. $1^{\circ}$ Abajo a la izquierda: arena y estructura vial. $2^{\circ}$ Abajo en el medio: vegetación, pared de roca y estructura vial. $3^{\circ}$ Abajo a la derecha: arena, vegetación y estructura vial. 
selectivity measure for use and availability data, within the home range, establishing selection in favor of the resource when the value is $>1$, no selection of resource when the value is = 1 and selection against the resource when the value is < 1 (Manly et al. 2002). We used Poisson regression to analyze the relationship between the climatic variables and the abundance of the species. All statistical analyzes were performed using the software R 3.4.0 (R Development Core Team 2017), and the best models were selected with the Akaike Information Criterion (Burnham \& Anderson 2002).

\section{RESULTS}

The Zapallaren Tree Iguana inhabited environments with slopes between 0 and $70 \%$, with presence of rocky surfaces in some places, scattered stones, and debris in others; herbaceous and shrub vegetation were always present. The minimum observed temperature was $12.3^{\circ} \mathrm{C}$, while the maximum temperature was $19.5^{\circ} \mathrm{C}$ (mean $=14.5^{\circ} \mathrm{C}$ ), with cloudiness between 0 and $100 \%$. The variables such as distance to the tide line or rocky surface were not influential, nor were the atmospheric pressure and solar radiation.

\section{RSPF FOR HABITAT}

The model that best explained resource selection, among all the candidate models, was the one that considered the vegetation surface variable (Table 1). The exponential value of the vegetation surface slope (exp.b=1.01, Cl $95 \% 1.00$ 1.02) was positively related to the probability of resource selection of the species (Table 2), indicating that for each square meter of increased vegetation surface, a $1 \%$ increase in the probability of selection was expected (Fig. 2a).

\section{RSPF FOR CLIMATIC VARIABLES}

The model that best explained resource selection was the one that considered the cloudiness and wind speed variables (Table 1). The exponential value of the cloudiness slope (exp.b=0.03, Cl $95 \%$ 0.01-0.07) and wind speed slope (exp. $b=0.74, \mathrm{Cl} 95 \% 0.61-0.87$ ), was negatively related to the probability of resource selection of the species (Table 3 ). This indicates that for each $1 \%$ increase in cloudiness, we expect a $97 \%$ decrease in the probability of selection, while for each $1 \mathrm{~m} / \mathrm{s}$ increase in wind speed, we expected a $26 \%$ decrease in the probability of selection (Figs: $2 b, 2 c$ ).

\section{MANLY'S SELECTIVITY MEASURE}

After establishing the home ranges for the six groups identified, the existence of 13 resource units was determined between types of vegetation cover, ground and rock structures (Table 4). According to the use-availability criterion, the resource units selected by Zapallaren Tree Iguana varied according to the established home ranges and the availability ratios within them. There was no constant selection throughout the study area. While for the lizards from the home range 1 and 2 located immediately adjacent to the mouth of the El Culebron

TABLE 1. Selection of models according to the Akaike Information Criterion (AIC) to explain the resource selection (logistic regression) and abundance (Poisson regression) of Zapallaren Tree Iguana in Changa Beach (Coquimbo, Chile). / Selección de modelos según el Criterio de información de Akaike (CIA) para explicar la selección de recursos (regresión logística) y la abundancia (regresión de Poisson) del Lagarto de Zapallar en playa Changa (Coquimbo, Chile).

\begin{tabular}{llccc}
\hline Analyses & Models & AICc & $\Delta$ AICc & $\begin{array}{c}\text { Akaike } \\
\text { Weight }\end{array}$ \\
\hline Logistic & Presence $\sim$ Vegetation surface & 14.41 & 0.0 & 0.61 \\
Regression: & Presence $\sim$ Interior wall height + Vegetation surface & 15.81 & 2.3 & 0.19 \\
Habitat & Presence $\sim$ Height of vegetation + Vegetation surface & 16.38 & 2.9 & 0.14 \\
\hline Logistic & Presence $\sim$ Cloudiness + Wind speed & 299.15 & 0.0 & 0.31 \\
Regression: & Presence $\sim$ Cloudiness + Atmospheric pressure + Wind speed & 299.65 & 0.5 & 0.24 \\
Climate & Presence $\sim$ Wind direction + Cloudiness + Wind speed & 300.14 & 1 & 0.19 \\
\hline \multirow{2}{*}{ Poisson } & Abundance $\sim$ Cloudiness + Wind speed & 200.57 & 0.0 & 0.30 \\
Regression: & Abundance $\sim$ Cloudiness + Atmospheric pressure & 201.31 & 0.7 & 0.21 \\
Climate & Abundance $\sim$ Cloudiness + Atmospheric pressure + Wind speed & 200.96 & 1.3 & 0.16 \\
& Abundance $\sim$ Cloudiness + Atmospheric pressure + Solar radiation & 201.82 & 2.2 & 0.10 \\
\hline
\end{tabular}


wetland the most important resource was Rock Wall, the lizards from the other home ranges selected resources related to the vegetation, with the exception of the lizards from the home range 4 that selected Sand-Ground (Table 4).

\section{Abundance}

A mean of 13 individuals (for the entire area) site was recorded $(\mathrm{Cl} 95 \%$ 10-16 individuals) with a difference between juveniles and adults of 3 individuals $(\mathrm{Cl} 95 \% 0.5$ 4.9 individuals, $p=0.02$ ). The maximum count in one day was
26 individuals, while the minimum was zero (Table 5). The model that best explained the abundance was the one that considered the cloudiness and wind speed variables (Table 1 ). The exponential value of the cloudiness slope (exp. $b=0.05$, $\mathrm{Cl} 95 \% 0.03-0.10$ ) and the wind speed slope (exp.b=0.87, Cl $95 \%$ 0.81-0.94) was negatively related to the probability of increase of species abundance (Table 6). This indicates that for every $1 \%$ increase in cloudiness, the abundance of Zapallaren Tree Iguana decreased $95 \%$, while for each $1 \mathrm{~m} / \mathrm{s}$ of increase in wind speed, the abundance decreased $13 \%$ (Fig. 3).
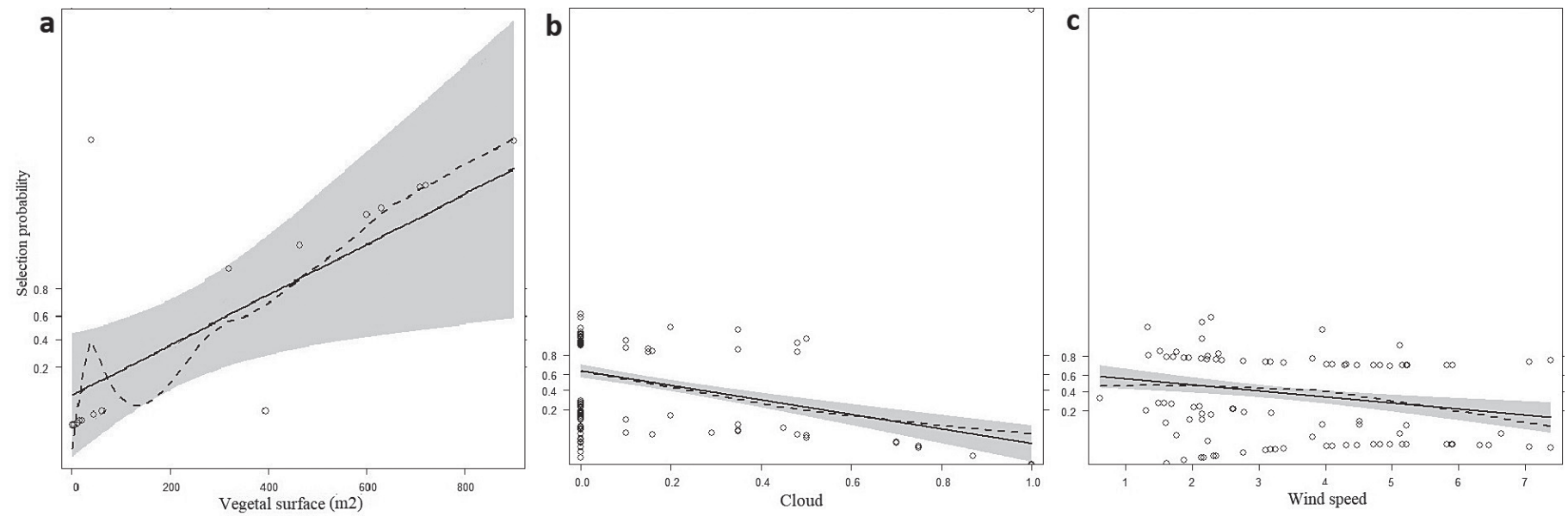

Figure 2. a: Positive effect of the Vegetation Surface habitat variable on the selection probability of Zapallaren Tree Iguana. b and c: Negative effect of climatic variables, cloudiness and wind speed on the selection probability of Zapallaren Tree Iguana. / a: Efecto positivo de la variable de hábitat superficie de la vegetación en la probabilidad de selección del lagarto de zapallar. byc: Efecto negativo de las variables climáticas, nubosidad y velocidad del viento en la probabilidad de selección del lagarto de zapallar.

TABLE 2. Parameters of the best logistic regression model for habitat variables that explained the selection of Zapallaren Tree Iguana resources in Changa Beach (Coquimbo, Chile). / Parámetros del mejor modelo de regresión logística para variables de hábitat que explicaron la selección de recursos del Lagarto de Zapallar en playa Changa (Coquimbo, Chile).

\begin{tabular}{lccccc}
\hline Model & b & Cl95\% & P & exp.b & Cl95\% \\
\hline Intercept & -2.39 & $-5.46 ;-0.60$ & 0.03 & 0.09 & $0.00 ; 0.55$ \\
Vegetation Surface & 0.01 & $0.00 ; 0.02$ & 0.02 & 1.01 & $1.00 ; 1.02$ \\
\hline
\end{tabular}

TABLE 3. Parameters of the best logistic regression model for climatic variables that explained the selection of Zapallaren Tree Iguana resources in Changa Beach (Coquimbo, Chile). / Parámetros del mejor modelo de regresión logística para variables climáticas que explicaron la selección de recursos del Lagarto de Zapallar en playa Changa (Coquimbo, Chile).

\begin{tabular}{lccccc}
\hline Model & $\mathbf{b}$ & $\mathrm{Cl} 95 \%$ & $\mathbf{p}$ & exp.b & $\mathrm{Cl} 95 \%$ \\
\hline Intercept & 1.63 & $0.87 ; 2.43$ & $<0.001$ & 5.11 & $2.40 ; 11.36$ \\
Cloudiness & -3.70 & $-4.84 ;-2.71$ & $<0.001$ & 0.03 & $0.01 ; 0.07$ \\
Wind speed & -0.31 & $-0.49 ;-0.14$ & $<0.001$ & 0.74 & $0.61 ; 087$ \\
\hline
\end{tabular}


TABLE 4. Description of the resource units of each home range and estimated selection rates of Zapallaren Tree Iguana ( $p$-values should be compared with Bonferroni level= 0.02). $\mathrm{W}_{\mathrm{i}}=$ Selection index. SE.W $\mathrm{W}_{\mathrm{i}}=$ Standard Error. $\mathrm{B}_{\mathrm{i}}=$ Standardized Selection index. / Descripción de las unidades de recursos de cada rango de hogar y coeficientes de selección estimados del Lagarto de Zapallar (los valores de $\mathrm{p}$ deben compararse con el nivel de Bonferroni $=0.02)$. Wi $=$ coeficiente de selección. $\mathrm{EE} . \mathrm{Wi}=$ Error estándar. $\mathrm{Bi}=$ coeficiente de selección estandarizado.

\begin{tabular}{|c|c|c|c|c|c|c|c|}
\hline & Resource Units & Available & Use & $W_{i}$ & SE.W & $\mathrm{p}$-value & $B_{i}$ \\
\hline \multirow{4}{*}{$\begin{array}{l}\text { Home } \\
\text { Range } 1\left(1019.65 \mathrm{~m}^{2}\right)\end{array}$} & $\begin{array}{l}\text { Rock Wall (RW): Large rocks placed to protect } \\
\text { the pedestrian lane and the highway }\end{array}$ & 0.15 & 0.33 & 2.22 & 0.57 & 0.03 & 0.53 \\
\hline & $\begin{array}{l}\text { Herbaceous Vegetation (HV): Vegetable cover } \\
\text { dominated by Nolana }\end{array}$ & 0.42 & 0.60 & 1.43 & 0.21 & 0.04 & 0.34 \\
\hline & $\begin{array}{l}\text { Footpath }(F) \text { : Pedestrian path without } \\
\text { vegetation }\end{array}$ & 0.07 & 0.03 & 0.48 & 0.47 & 0.26 & 0.11 \\
\hline & $\begin{array}{l}\text { Sakixornia - Paspalum (S-P): Vegetable cover } \\
\text { dominated by Salicornia fruticosa and Paspalum } \\
\text { vaginatum }\end{array}$ & 0.36 & 0.03 & 0.09 & 0.09 & 0.00 & 0.02 \\
\hline \multirow{4}{*}{$\begin{array}{l}\text { Home } \\
\text { Range } 2\left(1482.03 \mathrm{~m}^{2}\right)\end{array}$} & Rock Wall (RW) & 0.05 & 0.14 & 2.79 & 0.61 & 0.00 & 0.42 \\
\hline & Herbaceous Vegetation (HV) & 0.25 & 0.47 & 1.89 & 0.18 & 0.00 & 0.29 \\
\hline & $\begin{array}{l}\text { Rock Wall-Herbaceous Vegetation (RW-HB): } \\
\text { Combination of RW and HB }\end{array}$ & 0.17 & 0.29 & 1.73 & 0.24 & 0.00 & 0.26 \\
\hline & $\begin{array}{l}\text { Herbaceous Vegetation-Paspalum vaginatum } \\
\text { (HV-Pv): Combination of } \mathrm{HV} \text { and } \mathrm{PV}\end{array}$ & 0.53 & 0.09 & 0.18 & 0.05 & 0.00 & 0.03 \\
\hline \multirow{3}{*}{$\begin{array}{l}\text { Home } \\
\text { Range } 3\left(530.33 \mathrm{~m}^{2}\right)\end{array}$} & Herbaceous Vegetation (HV) & 0.61 & 0.71 & 1.16 & 0.11 & 0.13 & 0.49 \\
\hline & $\begin{array}{l}\text { Dry Herbaceous Vegetation (DHV): Dead } \\
\text { herbaceous vegetation dried by the effect of } \\
\text { time }\end{array}$ & 0.26 & 0.27 & 1.04 & 0.25 & 0.87 & 0.44 \\
\hline & $\begin{array}{l}\text { Shrub Vegetation (SV): Shrub vegetation } \\
\text { dominated by Tessaria absinthioides }\end{array}$ & 0.13 & 0.02 & 0.16 & 0.16 & 0.00 & 0.07 \\
\hline \multirow{3}{*}{$\begin{array}{l}\text { Home } \\
\text { Range } 4\left(921.22 \mathrm{~m}^{2}\right)\end{array}$} & $\begin{array}{l}\text { Sand-Ground (S-G): Substrate formed by the } \\
\text { mixture of sea sand and land filling }\end{array}$ & 0.42 & 0.57 & 1.36 & 0.26 & 0.16 & 0.48 \\
\hline & Shrub Vegetation (SV) & 0.31 & 0.29 & 0.92 & 0.32 & 0.81 & 0.33 \\
\hline & $\begin{array}{l}\text { Sparce Shrub Vegetation (SSV): SV scattered } \\
\text { on the ground }\end{array}$ & 0.27 & 0.14 & 0.53 & 0.28 & 0.10 & 0.19 \\
\hline \multirow[t]{3}{*}{$\begin{array}{l}\text { Home } \\
\text { Range } 5\left(490.40 \mathrm{~m}^{2}\right)\end{array}$} & $\begin{array}{l}\text { Debris Herbaceous Vegetation-Dry } \\
\text { Herbaceous Vegetation (DHV-DHV): } \\
\text { Combination of HV with debris and HV with } \\
\text { sand }\end{array}$ & 0.21 & 0.50 & 2.41 & 0.44 & 0.00 & 0.67 \\
\hline & Sand (S) & 0.50 & 0.37 & 0.74 & 0.18 & 0.15 & 0.21 \\
\hline & Herbaceous Vegetation (HV) & 0.30 & 0.13 & 0.45 & 0.21 & 0.01 & 0.13 \\
\hline \multirow{3}{*}{$\begin{array}{l}\text { Home } \\
\text { Range } 6\left(731.67 \mathrm{~m}^{2}\right)\end{array}$} & $\begin{array}{l}\text { Dry Plants Residues (DPR): Residues of dead } \\
\text { and dried plants by time }\end{array}$ & 0.06 & 0.31 & 5.13 & 1.23 & 0.00 & 0.74 \\
\hline & $\begin{array}{l}\text { Ground-Scattered Stones (G-SS): Stones } \\
\text { scattered on the ground }\end{array}$ & 0.11 & 0.13 & 1.17 & 0.49 & 0.73 & 0.17 \\
\hline & Herbaceous Vegetation (HV) & 0.83 & 0.56 & 0.68 & 0.10 & 0.00 & 0.10 \\
\hline
\end{tabular}


TABLE 5. Mean values of abundance (number of individuals per $900 \mathrm{~m}^{2}$ ) of Zapallaren Tree Iguana in Changa Beach (Coquimbo, Chile). / Valores promedio de abundancia (número de individuos por 900 m2) del Lagarto de Zapallar en playa Changa (Coquimbo, Chile).

\begin{tabular}{lccccc}
\hline & Abundance (Cl95\%) & Juveniles & Adults & Difference (CI95\%) & $\mathbf{p}$ \\
\hline Mean & $13(10-16)$ & 8 & 5 & $3(1-5)$ & 0.02 \\
Maximum & 26 & 17 & 11 & 8 & \\
Minimum & 0 & 0 & 0 & 0 & \\
\hline
\end{tabular}

TABLE 6. Parameters of the best Poisson regression model for climatic variables that explained the abundance (number of individuals) of Zapallaren Tree Iguana in Changa Beach (Coquimbo, Chile). / Parámetros del mejor modelo de regresión de Poisson para variables climáticas que explican la abundancia (número de individuos) del Lagarto de Zapallaren playa Changa (Coquimbo, Chile).

\begin{tabular}{lccccc}
\hline Model & $\mathbf{b}$ & $\mathrm{Cl} 95 \%$ & $\mathbf{p}$ & exp.b & \multicolumn{1}{c}{ Cl95\% } \\
\hline Intercept & 3.17 & $2.90 ; 3.43$ & $<0.001$ & 23.74 & $18.08 ; 30.97$ \\
Cloudiness & -2.93 & $-3.63 ;-2.32$ & $<0.001$ & 0.05 & $0.03 ; 0.10$ \\
Wind speed & -0.13 & $-0.21 ;-0.07$ & $<0.001$ & 0.87 & $0.81 ; 0.94$ \\
\hline
\end{tabular}
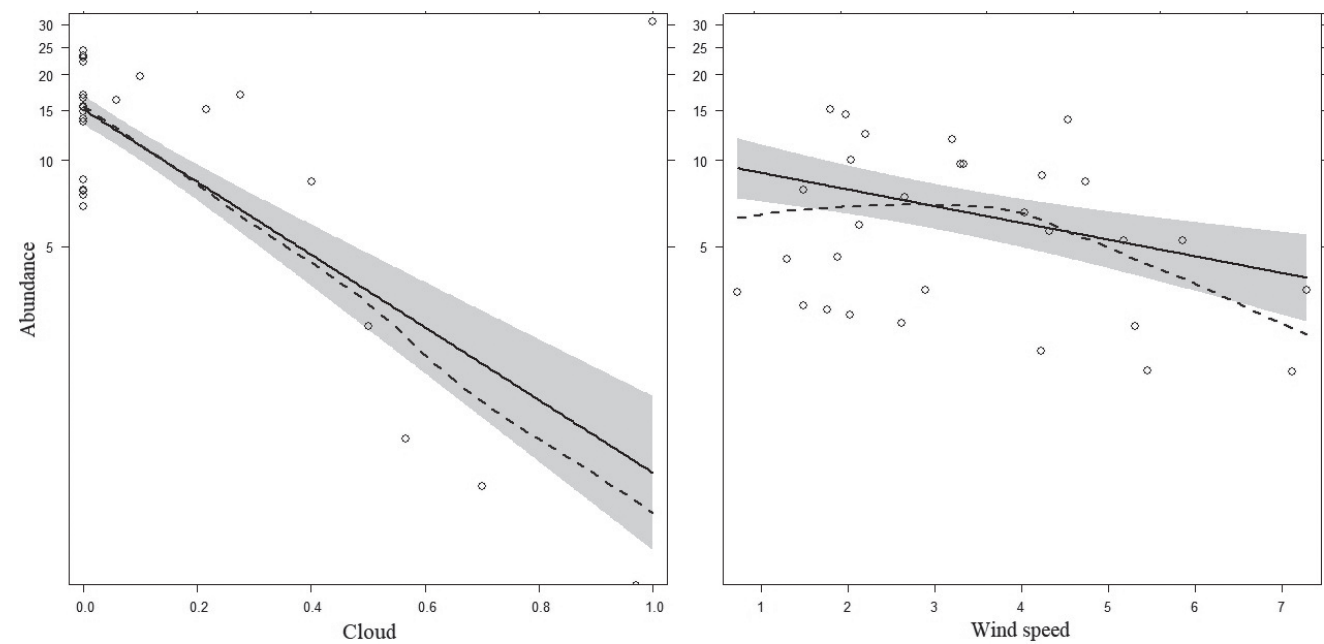

Figure 3. Negative effect of climatic variables cloudiness and wind speed on the abundance of Zapallaren Tree Iguana. / Efecto negativo de las variables climáticas, nubosidad y velocidad del viento en la abundancia del lagarto de zapallar.

\section{DISCUSSION}

This study shows that Zapallaren Tree Iguana exhibits a strong habitat selection at a local scale, and climatic and landscape variables mold its distribution and abundance. Our conclusions are restricted to winter season and juvenile/adult data. However, the season, sex, age class, behavioral activity, often affect resource selection and daily activity patterns of the animal studied (Schooley 1994, McKnight \& Hepp 1998, Boyce et al. 2002; Manly et al. 2002). This could be especially important in summer, when thousands of tourists daily visit the beach. In addition, because of the limited geographical scope of this study, we cannot extrapolate the RSPF to other areas inhabited by the species (Manly et al. 2002).

The vegetation cover was an important variable for habitat selection, because it allows Zapallaren Tree Iguana to hide in the presence of possible predators like Nycticorax nycticorax, Elanus leucurus, Parabuteo unicinctus, Athene cunicularia and Falco sparverius, present in the study area (Chávez-Villavicencio et al. 2015). Indeed, animals seek refuge in the vegetation 
every time the observer was close. Indeed, habitat structure occupation is correlated with escape behavior in different Liolaemus species (Schulte et al. 2004). The vegetation cover also allows for the protection of the accesses to their retreat sites or burrows, which are important places for survival (Kerr et al. 2003). Increase in cloudiness and wind speed during this study only conditioned the detection of individuals, which leads to confirm the approach of Schlesinger \& Shine (1994), who mentioned that individuals within their habitat are rarely located at random, as they usually choose areas with characteristics that favor their development.

The thermoregulatory activity of the species drives the selections of the resource units found in this study, specifically behavioral thermoregulation (Bartholomew 1982). The rock wall and the spaces left by the vegetation through which sunlight passes would be the most important habitat characteristics. The selection of rock wall coincides with the selection made by other reptile species, mainly because they produce a better heat accumulation and have high thermal conductivity over the stones (Clauser \& Huenges 1995), allowing to maintain optimal body temperatures to have a good performance in their physiological processes, to search for food, reproduce and escape from predators (Huey 1982). This diurnal heliothermic regulation seems is a common for Liolaemus species (Schulte et al. 2004, Labra et al. 2008). Our observations, however, did not account for other types of activity (e.g. feeding or grooming). However, we know that reptiles use their home ranges to provide themselves with food and other resources, including avoiding predators (Powell \& Mitchell 2012).

The cloudiness and wind speed modified the abundance of the species in the study area. When these variables were favorable, we made records of up to 26 individuals in a single evaluation day. Mella (2017), found that the species is frequent and abundant in its geographical distribution range. However, we could not find more references on its abundance. We need new studies to explore possible ontogenetic shifts in resource use and dispersal strategies to avoid intraspecific competition.

In summary, our study shows that the Zapallaren Tree Iguana has adapted its habitat selection strategy in an urbanized beach of northern Chile. Even highly urbanized areas may be able to provide a suitable habitat for the wildlife. Future studies should be aimed at understand patterns habitat selectivity of the Zapallaren Tree Iguana across different environmental conditions (with different regimes of anthropogenic impact), and its consequences on individual fitness, population dynamics, and biotic interactions with other sympatric species.

\section{ACKNOWLEDGMENTS}

We thank to D. Contreras for helping in the fieldwork and D. Cabrera for reviewing the text. This work was supported by the Ph.D. Program in Applied Biology and Ecology of the Universidad Católica del Norte.

\section{REFERENCES}

Bartholomew, G.A. 1982. Energy metabolism. En: Gordon, M.S. (Ed) Animal Physiology: principles and adaptations: 4693. Macmillan, New York, USA.

Burnham, K.P., Anderson, D.R. 2002. Model selection and inference: a practical information-theoretic approach. Second edition. Springer-Verlag, New York.

Boyce, M.S., Vernier, P.R., Nielsen, S. E., Schmiegelow, F.K.A. 2002. Evaluating resource selection functions. Ecological Modelling 157: 281-300.

Chávez-Villavicencio, C., Molina-Pérez, P., Tabilo-Valdivieso, E. 2015. Respuesta de la riqueza de aves en presencia de visitantes, vehículos y perros en el humedal "El Culebrón", Chile. The Biologist (Lima) 13(2): 313-327.

Clauser, C., Huenges, E. 1995. Thermal conductivity of rocks and minerals. En: Ahrens, T.J. (Ed) Rocks Physics and Phase Relations: a handbook of physical constants: 105-126. American Goephysical Union.

Davis, B.N.K. 1976. Wildlife, urbanisation and industry. Biological Conservation 10: 249-291.

Fernández-Juricic, E. 2004. Spatial and temporal analysis of the distribution of forest specialists in an urban fragmented landscape (Madrid, Spain): implications for local and regional bird conservation. Landscape and Urban Planning 69 (1): 17-32.

Fox, S.F., Shipman P.A. 2003. Social behavior at high and low elevations: environmental release and phylogenetic effects in Liolaemus. En: Fox, S.F., McCoy, J.K., Baird, T.A. (Eds) Lizard social behavior: 310-355. Johns Hopkins University Press, Baltimore.

Fuentes, E.R., Jaksić, F.M. 1980. Ecological species replacement of Liolaemus lizards along a habitat gradient. Oecologia 46: 45-48.

Gill, D., Bonnett, P. 1973 Nature in the urban landscape. York Press, Baltimore. 523 pp.

Goodman, B.A., Miles, D. B., Schwarzkopf, L. 2008. Life on the rocks: habitat use drives morphological and performance evolution in lizards. Ecology 89: 3462-3471.

Huey, R. 1982. Temperature, physiology and the ecology of reptiles, En: Gans, C., Pough, F.H. (Eds) Biology of the Reptilia: 25-91. Academic Press, New York. 
Kerr, G.D., Bull, M.C., Burzacott, D. 2003. Refuge sites used by the scincid lizard Tiliqua rugosa. Austral Ecology 28: 152160.

Koenig, J., Shine, R., Shea, G. 2001. The ecology of an Australian reptile icon: how do blue-tongue lizards (Tiliqua scincoides) survive in suburbia? European Journal of Wildlife Research 28: 215-227.

Labra, A., Vidal, M., Solís, R., Penna, M. 2008. Ecofisiología de Anfibios y Reptiles. En: Vidal, M., Labra, A. (Eds) Herpetología de Chile: 483-516. Science Verlag, Santiago.

Lobos, G., Marambio, Y., Ruiz de Gamboa, M., Valladares, P. 2016. Liolaemus zapallarensis. The IUCN Red List of Threatened Species 2016: e.T12011A69941220. URL: http://dx.doi.org/10.2305/IUCN.UK.2016-1.RLTS. T12011A69941220.en

Losos, J.B., Marks, J.C., Schoener T.W. 1993. Habitat use and ecological interactions of an introduced and a native species of Anolis lizard on Grand Cayman, with a review of the outcomes of anole introductions. Oecologia 95: 525-532.

Manly, B.F.J., McDonald, L.L, Thomas, D.L., McDonald, T.L., Erickson, W.P. 2002. Resource selection by animals: statistical design and analysis for field studies. 2nd ed. Dordrecht, The Netherlands: Kluwer Academic Publishers. 209 pp.

McKnight, S., Hepp, G. 1998. Diet selectivity of gadwalls wintering in Alabama. Journal of Wildlife Management 62: 1533-1543.

Medel, R., Marquet, P. Jaksić, F. 1988. Microhabitat shifts of lizards under different contexts of sympatry: a case study with South American Liolaemus. Oecologia 76: 567-569.

Mella, J. 2017. Guía de Campo de Reptiles de Chile. Tomo 1: Zona Central. Peñaloza A.P.G. (Ed) Santiago, Chile. 320 pp.

Powell, R.A., Mitchell, M.S. 2012. What is a home range? Journal of Mammalogy 93: 948-958.

R Core Team. 2017. R: A language and environment for statistical computing. $\mathrm{R}$ version 3.6.1. The $\mathrm{R}$ Foundation for Statistical Computing, Vienna, Austria. URL: https:// www.R-project.org.

Sierra, M. 2012. Ciudad y fauna urbana. Un estudio de caso orientado al reconocimiento de la relación hombre, fauna y hábitat urbano en Medellín. Tesis de Magíster. Universidad Nacional de Colombia. Colombia.

Schlesinger, C.A., Shine, R. 1994. Choosing a rock: perspectives of a bush-rock collector and a saxicolous lizard. Biological Conservation 67: 49-56.

Schooley, R. 1994. Annual variation in habitat selection: patterns concealed by pooled data. Journal of Wildlife Management 58: 367-74.

Schulte, J., Losos, J. Cruz, F., Núñez, H. 2004. The relationship between morphology, escape behaviour and microhabitat occupation in the lizard clade Liolaemus (Iguanidae: Tropidurinae*: Liolaemini). Journal of Evolutionary Biology 17: 408-420.

Simonetti, J.A., Ortiz, J.C. 1980. Dominio de Liolaemus kuhlmanni (Reptilia: Iguanidae). Anales del Museo de Historia Natural de Valparaíso 13: 167-172.

Smith, G.R., Ballinger, R.E. 2001. The ecological consequences of habitat and microhabitat use in lizards: a review. Contemporary Herpetology 3: 1-37.

Taylor, D., Daniels, C.B., Johnston, G. 2016. Habitat selection by an arboreal lizard in an urban parkland: not just any tree will do. Urban Ecosystems 19(1): 243-255.

Tulli, M.J., Cruz, F.B, Herrel, A. Vanhooydonck, B. Abdala, V. 2009. The interplay between claw morphology and microhabitat use in neotropical iguanian lizards. Zoology 112: 379-392.

Worton, B.J. 1989. Kernel Methods for estimating the utilization distribution in home range studies. Ecology 70: 164-168.

Received: 23.04.2019

Accepted: 03.03.2020 